\title{
External Reserves and Selected Key Macroeconomic Variables in Nigeria: An Empirical Analysis (2000-2018) ${ }^{1}$
}

\author{
Olorunsola E. Olowofeso, Isaiah O. Ajibola, Rabia A. Muhammad, Suleiman Karu and Offiong E. Orenowo \\ Statistics Department, Central Bank of Nigeria, Abuja
}

\begin{abstract}
The paper determines empirically the interactive influence of external reserves and selected key macroeconomic variables in Nigeria using an autoregressive distributive lag (ARDL) model, cointegration and error correction model anticipated by Pesaran, Shin and Smith (2001) with quarterly data between 2000 and 2018 sourced from Central Bank statistics portal on data warehouse pro platform at https://cbnstatistics.datawarehousepro.com. The paper applied the Augmented Dickey-Fuller (ADF) unit root in testing variables stationarity. The Cumulative sum (CUSUM) as well as the Cumulative sum of square (CUSUMSQ) display some recursive outstanding schemes of the external reserve function that remain within the $5 \%$ critical positions, and therefore gave an indication of steady external reserve purpose for Nigeria during the study period. The key variables trade openness that captured the total imports and exports by way of proportion of gross domestic product (GDP), exchange rate, direct investment, portfolio investment, oil price, consumer price index, interest rates have correct signs and the ARDL regression analysis indicates that the descriptive variables elucidate and accounted for $99 \%$ disparities in external reserves model. The bounds cointegration test exhibited that the variables are cointegrated. The paper demonstrated several empirical supports for the theoretical implications. Precisely, the log of direct investment, portfolio investment, trade openness and interest rate have positive effect, statistically significant and contributes to the external reserves position in Nigeria on the short- run.
\end{abstract}

JEL. Classification Numbers: F21, F32, F34

DOI: $10.7176 / \mathrm{JESD} / 11-10-08$

Publication date:May $31^{\text {st }} 2020$

\subsection{Introduction}

External reserves, also called foreign reserves, consists of outward capital which are willingly accessible to and regulated by Central Banks to assist balance of payments funding requirements, participation in foreign exchange souks to influence the money rates, as well as other connected objectives like upholding assurance in the exchange and the finance, and helping as a foundation for lending (IMF, 2009).

Emerging economies and the world at large, especially the oil exporting nations, are engaged in the accumulation of reserve. This is as a result of the knowledge of enormous investment reversals in Asian economies in the 1990's (Usman and Ibrahim, 2010) that has devastating huge effects on their current accounts. In the past, only gold and silver were used as external reserve but following the world bank and the International monetary fund structure between1944-1968, the American convertible currency (USD) was converted into gold and included as reserve currency thereby making it the Nation's official international reserve assets. The conversion of gold by both institution and individuals was restricted and finally cancelled in 1973 and since then no key moneys were exchangeable to gold from authorized gold assets. Even with the cancellation of conversion of currencies to gold, some currencies such as USD, Pounds sterling, Swiss Franc and Japanese yen still serve as nation's reserves currency with the USD contributing the dominant portion in the global reserve as a result of penetration and liquidity in US market for treasury and agency securities (Oputa, 2002).

There has been research by several scholars on external reserves and concerns has been on the adequacy of external reserves, the rewards and shortcomings of possessing surplus reserves, rationale aimed at holding reserves, reserves level etc. Regardless of the much research, there seems to be a gap and contradiction in the works concerning the question of how external reserves accumulation impacts on macroeconomic variables. The debate likewise drew acute criticisms from others who questioned the justification for accumulating reserves in the face of decaying infrastructures and high prevalence of poverty in the country (Ibrahim 2010).

According to Ghosh et al (2012), there are numerous reasons why countries accumulate reserves though it differs depending on nation's situation and international reserves' spreading. Countries holding high reserves, are usually more economically unified, are encouraged by assurance contrary to asset account instead of current account shockwaves, are conscious to the price of possessing reserves than countries with smaller-reserves. Exchange underestimation is an important factor in reserves spreading (Ghosh, et.al (2012). Reserves accumulation in developing nations is interrelated with a higher rate of economic progress and is fast when the foreign exchange is controlled by GDP or exports (Borivoje and Tina, 2015). Elhiraika and Ndikumana (2007),

${ }^{1}$ The views and opinions expressed in this paper are those of the authors and do not necessarily reflect the official policy or position of the Central Bank of Nigeria. 
noted that developing countries accumulate reserves to allow Central banks intercede in souks to regulate rates of consumer price index and exchange, to enable the country borrow from developed economies as well as guide against uncertainties of external investment flows; economic and social costs which could emanate from insignificant earnings on capital, impairment as a result of foreign exchange devaluation and foreign earnings from capital as well as public disbursements which might be funded using reserves. Reserve accumulation help in stabilizing the economy, this is when the central banks mediate in markets to impact the exchange and inflation rates.

The Central Bank of Nigeria (CBN) holds reserves to deal with exchange rate volatility, as a shockwave stabilizer in times of financial tremors, settlement of international trade, and means of holding Sovereign Wealth Fund (SWF). These reasons for holding reserves gives rise to the question of this study; "does accumulation of reserve or its depletion have impact on the economy of Nigeria?". Olokoyo et al (2009) scrutinized collaborative influence of reserve on some macroeconomic variables between the period 1970 and 2007 in Nigeria and concluded that accumulation of reserve is not very productive in Nigeria.

From the works by some scholars on the investigation of External reserves and some macroeconomic variables in Nigeria and the international community in general, it was found that there have been both positive and negative impacts of accumulation of external reserves on the nation's economy. Hence, the significance of this research is to add to the existing knowledge and offer recommendations to the government on how to ease the risk and negative effects of accumulating reserves in the country.

The aim of this research is an extension of the work of Olokoyo et. al (2009) by examining the movements and collaboration between international foreign exchange in Nigeria and relationship of reserves on various macroeconomic variables like GDP, foreign capital flow, trade openness, oil price and exchange, inflation, and interest rates during the period 2000 Q1 and 2018 Q4 using the ARDL. The inclusion of key macroeconomic variables and the time period considered is quite unique.

The paper is arranged in five parts viz first part is the introduction, part two handles literature review; part three treats research methodology and part four presents data, results and discussion. Part five is the concluding remarks of the paper.

\subsection{Literature Review}

\subsection{Theoretical Fiction}

There have been several discussions and opinions on external reserve by some scholars; the reason for reserve accumulation, adequacy, determinants, etc. In assessing the adequacy of reserve, IMF (2011) enlightened on the significance of possessing suitable reserve as fragment of a nation's defense in contradiction of shocks. Even though thorough inclusive strategy frameworks were perhaps the most significant purpose, liquidity cushions help flat consumption throughout the crises, and empowered some nations to accomplish huge diminutions without undergoing an expensive disaster.

Frenkel and Jovanovic (1981) in their work viewed reserves as a buffer stock to permit stochastic variations in outward transactions. Since modification costs could be sustained each time reserves attain a lower bound, it will be ideal to maintain a level of reserves that can hold the unpredictability of external dealings and evade such modification.

In a way, foreign reserves indicate the strength of a nation, Greenspan (1999) argued that economies with feebler currencies ostensibly grasp international reserves because they notice the insurance worth of such reserves could be equivalent of their cost in actual possessions. According to him, reserves, similar to all other monetary asset, have worth but include cost. Consequently, the alternative to build reserves, and in what amounts, is continuously a tough cost-benefit compromise.

Generally, reserves are held for exchange rate targeting, credit worthiness, foreign exchange market stability, dealings cushioning and disaster such as natural tragedy (Archer and Halliday, 1998 and Humphries, 1990). However, there are risks involved in the accumulation of reserve. When the reserves are held in excess, instead of preventing economic disaster, they might weaken the global economic scheme in the elongated term. Also, they might increase the accumulation of international disparity in countries with current account surplus (Steiner, 2010).

According to Fischer (2001), "Reserves matter because they are the key determinant of a country's ability to avoid economic and financial crisis. This is true of all countries, but especially the emerging markets that are open to volatile international capital flows. The availability of capital flow to offset current account shocks reduce the amount of reserves a country need. But access to private capital is often uncertain, and inflows are subject to rapid reversals. As was seen in the financial crisis of the late 1990s and the recent global financial crisis, countries with robust foreign reserves, by and large, did better in withstanding the contagion than those with smaller foreign reserves".

IMF (2003) established real per capita GDP, proportion of importations to GDP, instability of the exchange rate, population level as possible factors that determines external reserves holding and at the same time are stochastically connected with reserve whereas opportunity cost and capital account susceptibility were not. 
According to Heller and Khan (1978), reserve accumulation can be influenced by the floating exchange rate regime. They identified it as a perilous feature that impacts the level of reserves adequacy. In their submission, they observed that for industrialized nations their reserves adequacy moves downwards, although most unindustrialized nations the level tends to increase. They posit that more elastic exchange rate managements can accept shockwaves to the economy, and therefore need negligible liquidity buffers. Nevertheless, the necessity for reserves may rise with exchange rate pliability to temper exchange rate movements if investments are unpredictable.

Conversely, there have been controversies between the monetarist and Keynesian on the accumulation of reserve, and based on this there are some theories applied. According to the monetarist, accumulation of reserve is because of the surplus claim for the local currency and the development of the international trade. In respect to Keynesian, accretion of external reserve will increase the current account hence it will absolutely influence cumulative input in the short term; this could disrupt the nominal exchange rate. Additional concept is the adaptability method that observes outcome of an appreciation or devaluation of the exchange rate on reserve movements in an economy. The method stipulates in a descending modification of exchange rates, a country undergoing a balance of payment imbalance must increase exports and decrease imports and consequently accrue additional reserves.

In some unindustrialized nations of Africa and East Asia, there has been massive accumulation of external reserve regardless of economic implication on macro economy (Umeora, 2013). Reserves accretion can carry a huge opportunity cost for African nations and indicate economical sponsoring of the shortfalls for reserve capital nations. The accumulation is accompanied by appreciation of national currencies which in a way destabilizes export competitiveness and hinders energies meant at diversification of exports. Reserves can distort development through the exports and asset networks. It can negatively affect local asset and employment generation and limit growth towards attaining national expansion objectives. (Elhiraika and Ndikumana, 2007, Kevin G. et al 2009).

\subsection{Empirical Literature}

Elhiraika and Ndikumana, (2007) in their contribution, examined the motivations, foundations, and influence of the reserves accretion, with concentration on the effect of main macroeconomic variables such as public and private asset, the exchange rate, and inflation. Using Kao and Pedroni (1996) co-integration tests that notify requirement of the models in order to circumvent false regressions, they came up with the result that reserves speculation could not vindicated the revenues to investments contemplations, assumed the low international interest rates and the high rates of earnings to local investments in sub-sahara African nations. A main outcome of the experimental scrutiny is reserves accretion had been attended by increase in the value of domestic moneys. However, their evidence suggested that central banks were efficacious in encompassing the process of reducing taxes and or increasing government expenditures impacts of international reserves inflows, especially by curtailing it's influence on money supply. The approach emanates at a price as it avoids nations benefit from exports growth and international assets influxes to arouse local asset.

Usman and Ibrahim (2010) utilize a blend of Ordinary Least Squares (OLS) and Vector Error Correction (VEC) approaches to examine the influence of variation in foreign exchange positions of Nigeria scheduled local asset, inflation and exchange rates, it was noticed that variation in foreign exchange impacts FDI and exchange rates, but had no impact on local asset and consumer price index. The outcomes recommended wider reserve administration approaches could take full advantage of the improvements in crude oil export returns using more capitals for domestic asset enhancement.

In some Asian countries, as researched by Lin and Wang (2005), using the method originated by Kyaland and Prescott (1977), the relationship between the external reserve and the inflation showed that when the external reserves increases, the consumer price index (CPI) will be increasing even though exchange rate impact was robust. However, CPI will decrease once the economic shock impact could be prevailing while the heaviness attached on yield steadiness is minimal.

Marc-Andre Gosselin \& Nicholas Parent (2005) by means of OLS technique noted that reserve accretion by monetary authorities in developing Asia estimated reserve-demand technique using eight panels of Asian developing-souk economies and came up with an opinion that since past relationships remain to be true, a slowpace stride of reserve accretion is possible. Their outcome suggests undesirable risks for the USD. Though, the considerable asset impairments that Asian monetary authorities would sustain if they were to radically alter their holding strategy alleviate the risks of a speedy depreciation of the USD activated by Asian monetary authorities.

Umeora (2013) examined the relationship between External Reserves Accumulation, Exchange Rate and GDP using a simple linear regression and found that there was an encouraging and substantial relationship amongst Exchange Rate, GDP and External Reserve accretion. External reserve has substantial positive impact on the measure of exchange rates of domestic currency (Naira) to USD at diversification of exports.

Kruskovic and Maricic (2015) studied the pragmatic investigation of the influence of external reserves on economic development in developing economies and came up with the result that exchange rate devaluation 
happens due to reserve accretion that is not provoking since it is non-tenacious shockwave different from abrupt devaluation of the exchange rate which happens due to sustaining overestimated exchange rate in the long run which could result to currency catastrophe. Accretion to external reserve will not result to inflation provided the proportion of external reserve accretion will not surpass economic development rate. Their finding suggests that the upsurge in external reserves results to the expansion of the GDP, while in the contrary direction, interconnection has not been established.

Fukuda and Kon (2010) in their work explored the possible long-run impacts of the accumulation of external reserve on macroeconomic variables in emerging nations by analyzing a less complex undeveloped economy investigation wherever improved foreign exchange reserves diminish expenses of liquidity hazard. They used unbalance panel data of 135 countries as obtainable in Penn World Table. The different nations indication showed a rise in external reserves consequently increases international loan remaining as well as curtails loan maturity. The outcomes suggested augmented external reserves could result to decrease consumption and improve asset and financial development. External reserves were found to be positively interrelated with investment rate and GDP growth. The positive influence on economic development, nevertheless, vanishes when the influence is being controlled through asset i.e., with the use of asset proportion as a regressor, reserve buildup immaterial for economic development.

Olokoyo et.al (2009) observed collaborative effect of international reserve on some macroeconomic variables using the ARDL and found a long-term connection amongst external reserves with some carefully chosen macroeconomic variables such as, level of trade trustworthiness, foreign investment inflow and inflation. The outcomes collected from the cointegration show minimum of two co-integrating models. Their observation established reasons that the extent of foreign exchange in Nigeria includes GDP, extent of trade openness, foreign asset influx and inflation. The extent of GDP and trade openness has positive influences on international reserves, supportive of theoretical base of external reserves. However, the extent of investment inflow and consumer price index had an adverse effect on external reserves, with a tendency to oppose accretion of reserves program of the CBN.

Alabi et. al (2017) investigated the causality between foreign exchange and financial growth in Nigeria, if it exist any influence of accruing reserve on the economic development and came up with the conclusion that, accumulating reserves does affect growth positively and there was an elongated term symmetry connection amongst the variables. Their findings revealed there was un-maneuvering interconnection from real GDP to the level of external reserves accrued; this means that economic growth causes an increase in external reserve.

Osuji and Ebiringa (2012) adopted a VAR model for multivariate analysis of external reserve on the macroeconomic indices to control extended term affiliation and to assess the consequence of macroeconomic volatility on the external reserve management between the years (1980-2009). The outcome of the VAR model revealed that external reserves is substantial in the contemporary period which appears to meet in the preceding years. Their result showed that the type, design and level of assets commodities and non-assets commodities influences external reserve management.

Kevin et al (2009) employed the empirical framework of Fukuda and Kon (2008) that designed a simple open economy model where accretion to external reserve increased the cost of liquidity risk to normalize the long run effects of foreign exchange on macroeconomic indices for a collection of minor Caribbean open emerging economies. They used a balanced panel data co-integration test and the Panel Dynamic OLS (PDOLS) estimation methods to examine the presence of exclusive co-integration relationship and derive the long run estimates. From their findings, it was revealed that external reserves have a significant adverse effect on consumption and loan maturity and a encouraging influence on exports and economic development. Also, there was no substantial relationship amongst asset and reserves. Furthermore, the outcome of international reserves on economic development was revealed to hinge on the level of import cover as well as the exports and consumption on the management of the interest rates.

\subsection{Research Methodology}

This study adopts the Autoregressive Distributive Lag Model (ARDL) in examining the causal relationship amongst the extent of external reserve buildup and some macroeconomic variables, and how these macroeconomic variables impacts on the level of external reserve. The macroeconomic variables included are GDP, exchange rate, consumer price index, oil price, trade openness, level of capital inflow (direct investment and portfolio investment) and interest rate. The ARDL modeling method was chosen because it is scientifically substantial to examine the co-integration relationship in insignificant samples, which allows different optimal lags of variables. It is desirable when handling indices which are integrated of diverse order, I (0), I (1) or consolidation of all and, strong in a single elongated term affiliation amongst the fundamental variables in a small sample size. In this study, series are integrated of both I (1) and I (0), hence there is need for bound co-integration test. 


\subsection{Gregory and Hansen Cointegration Test}

The Gregory and Hansen (1996) residual-based test for cointegration was used to test structural break in the cointegrating affiliation between the indicators of consideration. This method is excellent when compared with the Engle and Granger (1987) method which seems to reject the null hypothesis of no cointegration provided there is a cointegration affiliation which transformed through the sample time. The Gregory and Hansen test is known to be an abridged version of the Engle and Granger method.

\subsection{Model Specification and Estimation Method}

The comprehensive ARDL (p, q) model is stated as: $\mathrm{Y}_{\mathrm{t}}=\theta_{o j}+\sum_{i=1}^{p} \alpha_{j Y_{t-1}}+\sum_{i=1}^{q} \beta_{j} X_{t-1}+\varepsilon_{t}$

Where $\mathrm{y}_{\mathrm{t}}{ }^{1}$ is a vector and the variables $\mathrm{X}_{\mathrm{t}}$ are tolerated to be entirely $\mathrm{I}(0)$ or I(1) or cointegrated; $\alpha$ and $\beta$ are coefficients; $\theta$ is the constant; $\mathrm{j}=1, \ldots, \mathrm{k} ; p, q$ are optimum lag orders; $\varepsilon_{\text {it }}$ is a vector error terms-unobservable zero means white noise vector process. For dependent variables, $\mathrm{P}$ lags are used while exogenous variables use q lags. Having considered advantages of ARDL modeling method in which some are; conveying reliable approximations of long run restrictions which are asymptotically standard notwithstanding the order of integration and being able to differentiate amongst dependent and explanatory variables, this article denotes equation involving external reserves to many macroeconomic variables:

$E X T R=f(G D P, T R A D O, E X R, D I, P I, C P I, O P, I N T R)$

Equation (1) can be written clearly as follows:

$\log \left(E X T R_{t}\right)=\beta o+\beta_{1} \log \left(G D P_{t}\right)+\beta_{2} \log \left(T R A D O_{t}\right)+\beta_{3} \log \left(E X R_{t}\right)+\beta_{4} \log \left(D I_{t}\right)+\beta_{5} \log \left(P I_{t}\right)+\beta_{6} \log \left(C P I_{t}\right)+$ $\beta_{7} \log \left(O P_{t}\right)+\beta_{8} \log \left(I N T R_{t}\right)+\varepsilon_{t}$

where, EXTR is international reserves, GDP is gross domestic product; TRADO denotes extent of trade openness designated as the summation of import and export as a proportion of GDP, EXR is exchange rate (Naira to USD), $\mathrm{DI}$ is direct investment, $\mathrm{PI}$ is portfolio investment, which makes the investment flows to the economy, OP represent the oil price, CPI is Consumer price index, INTR is the interest rate, $\beta_{1-8}$ are parameters, and $\varepsilon_{t}$ is the error term. The variables were reported in log format for ease of comparability. The economic concept formed the origin for the a priori expectations that $\beta_{i}>0$; such that $i=1,2,3,4,5,6,7$ and 8

The study intends to conduct a unit root test to test the stationarity of the sequences and if the sequences are integrated of different orders that is, I (1) and I (0), then it would be advisable to access long run affiliation by means of bounds cointegration test as anticipated by Pesaran, et. al. (2001) with following ARDL model specification (from equation 2):

$\Delta L E X T R_{t}=\beta_{0}+\beta_{1} L E X T R_{t-1}+\beta_{2} L G D P_{t-1}+\beta_{3} L T R A D O_{t-1}+\beta_{4} L E X R_{t-1}+\beta_{5} L D I+B_{6} L P I_{t-1}+\beta_{7} L C P I t_{-1}+\beta_{8} L O P_{t-1}$ $+\beta_{9 \text { LINTRt }_{-1}}+\sum_{i=1}^{p} \beta_{i} \Delta L E X T R_{t-1}+\sum_{i=0}^{q 1} \beta_{2} \Delta L G D P_{t-1}+\sum_{i=0}^{q 2} \beta_{3} \Delta L T R A D O_{t-1}+\sum_{i=0}^{q 3} \beta_{4} \Delta L E X R_{t-1}+$ $\sum_{i=0}^{q 4} \beta_{5} \Delta L D I_{t-1}+\sum_{i=0}^{q 5} \beta_{6} \Delta L P I_{t-1}+\sum_{i=0}^{q 6} \beta_{7} \Delta L C P I_{t-1}+\sum_{i=0}^{q 7} \beta_{8} \Delta L O P_{t-1}+\sum_{i=0}^{q 8} \beta_{9} \Delta L I N T R_{t-1}+e_{t}$ (3)

Where $\beta_{1-9}$ are long - run multipliers. It follows then that our test for the level relationship have the following null and alternative hypotheses:

$\mathrm{H}_{0}=\beta_{1}=\beta_{2}=\beta_{3}=\beta_{4}=\beta_{5}=\beta_{6}=\beta_{7}=\beta_{8}=\beta_{9}=0$ (There is no co-integration)

$\mathrm{H}_{0} \neq \beta_{1} \neq \beta_{2} \neq \beta_{3} \neq \beta_{4} \neq \beta_{5} \neq \beta_{6} \neq \beta_{7} \neq \beta_{8} \neq \beta_{9} \neq 0$ (There exist co-integration)

The importance of conducting a bounds examination is to investigate if there are long run affiliation between the variables in above equation. The verdict law is null hypothesis will be rejected provided the critical F-statistic is larger than value for the upper bound I (1) at 5\% level of significance. In long and short run model is estimated when the null hypothesis is rejected because there is no cointegration. The estimation of the long run shows there is equilibrium and there is a short run ECM to gauge short run dynamic outcome. This could be recognized by means of ARDL constrained ECM such that long and short-run resistance amounts are attained. Following Pesaran and Pesaran (1997) principle of that short run dynamics are vital in examining steadiness of long-run as stated in equation (2) and estimating the following ECM thus.

$\triangle L E X T R_{t}=\beta_{0}+\beta_{1} L_{E X T R_{t-1}}+\beta_{2} L G D P_{t-1}+\beta_{3} L T R A D O_{t-1}+\beta_{4} L E X R_{t-1}+\beta_{5} L D I+B_{6} L P I_{t-1}+\beta_{7} L C P I t_{-1}+\beta_{8} L O P_{t-1}$ $+\beta_{9}$ LINTRt $_{-1}+\sum_{i=1}^{p} \beta_{1} \Delta L E X T R_{t-1}+\sum_{i=0}^{q 1} \beta_{2} \Delta L G D P_{t-1}+\sum_{i=0}^{q 2} \beta_{3} \Delta L T R A D O_{t-1}+\sum_{i=0}^{q 3} \beta_{4} \Delta L E X R_{t-1}+$ $\sum_{i=0}^{q 4} \beta_{5} \Delta L D I_{t-1}+\sum_{i=0}^{q 5} \beta_{6} \Delta L P I_{t-1}+\sum_{i=0}^{q 6} \beta_{7} \Delta L C P I_{t-1}+\sum_{i=0}^{q 7} \beta_{8} \Delta L O P_{t-1}+\sum_{i=0}^{q 8} \beta_{9} \Delta L I N T R_{t-1}+\lambda E C T_{t-1}+$ $e_{t}$

Where, $\Delta$ is the first difference operator, $\lambda$ is the error correction coefficient, ECT is the error correction term and other variables are as elucidated previously.

The initial portion of the model shows long-run dynamics of the equation. The study estimated ARDL model using a maximum of four (4) lags $\left(\mathrm{i}_{\max }=4\right)$ and Akaike info criterion (AIC).

The ARDL requires that, the model carries out the following diagnostic test; linearity test to ascertain whether the model is linear or it is correctly specified; the serial correlation test to ascertain the validity or otherwise of the estimates; heteroskedasticity test, if the adjustment of the error term is constant which could arise as a result of incorrect data transformation, incorrect functional form, incorrect specification of the regression model; normality 
test, was employed to examine if the residuals are normally distributed, as well as the CUSUM and CUSUMQ of recursive residuals.

\subsection{Data Description and Source}

The quarterly data spanning 2000:Q1 - 2018:Q4 was utilised. The data was sourced from the Central Bank of Nigeria (CBN) statistics portal on data warehouse pro platform and is also accessible at https://cbnstatistics.datawarehousepro.com. The various tests and estimation of regression were carried out with the use of E-views version 11.

\subsection{Estimation Techniques}

The cointegration and error-correction modeling technique was used for this study. In order to evaluate the cointegration and error-correction, the researchers examined the order of integration, cointegration and as well as the error correction model as discussed above.

\subsection{Unit-Root test}

In empirical research on time series data, there always exist problem of non-stationarity which makes the conventional models of econometrics like ordinary least squares unsuitable. To overwhelmed this problem of UnitRoot, the first strategy was to study stationarity of the time-series data. There are many tests that have been developed to test for stationarity, these consist of the Dickey Fuller (DF), Augmented Dickey-Fuller (ADF), Phillips-Perron (PP), Sarghan Bhangra Dubbin Watson (SBDW) tests. Of all, the ADF test is generally viewed as the most effective tool for integration. Accordingly, the ADF test used in this study.

The null hypothesis here is that all variables of the model exhibited non-stationary while the alternative proposition gave evidence of stationary. If variables examined turns out to comprise unit roots it implies, they are non-stationary. Stationarity could however be achieved by first differencing of the levels provided the sequence are integrated of order one i.e. I(1).

\subsection{Cointegration Test}

This recognize circumstances where two or more non-stationary time series are unified organized in a way that they cannot depart from symmetry in the elongated period. The tests are used to classify the impact of sensitivity of two variables to the same mean price over a stated period of time.

We could consider these sequences as explaining a lasting symmetry affiliation, as the modification amongst them is stationary (Hall and Henry, 1989). In a situation where there are no cointegration, it recommends that such parameters does not have long-run affiliation, they could meander randomly remotely with each other (Dickey et. al., 1991). The research used boundaries technique recognized in Pesaran et al., (2001).

\subsection{Error Correction Model (ECM)}

The ECM is used only to demonstrate the existence of cointegration; it involves creation of error correction apparatus to validate dynamic affiliation. The motive of ECM is to specify swiftness in modification from the short-run equilibrium to the long-run equilibrium state. The larger the co-efficient of the parameter, the swifter the speed of alteration of the model from the short-run to the long-run. As seen in equation (4) is the illustration of an error correction form that permits for enclosure of long-run data.

\subsection{Data, Results and Discussion}

Data was obtained from the CBN statistics portal on data warehouse pro platform and is also accessible at https://cbnstatistics.datawarehousepro.com. All the required conversions are done on the variables in order to confirm the model in a stationary, log linear form.

The various tests and estimation of regression were carried out with the use of E-views version 11. 
Table 1: Summary Statistics

$\begin{array}{llllllll}\text { LEXTR LEXR LCPI LDI LGDP LINTR LOP LPI LTRADO } & \text { LP }\end{array}$

Mean $\quad \begin{array}{llllllllll} & 10.15569 & 5.037183 & 4.564958 & 11.83918 & 16.27064 & 2.499947 & 4.061159 & 11.14251 & 2.168011\end{array}$

$\begin{array}{llllllllll}\text { Median } & 10.40119 & 5.002914 & 4.575573 & 11.98626 & 16.33757 & 2.564949 & 4.117924 & 11.34295 & 2.270787\end{array}$

$\begin{array}{lllllllllll}\text { Maximum } & 11.03621 & 5.725911 & 5.615206 & 13.46567 & 16.76213 & 3.020425 & 4.846913 & 14.26649 & 2.821432\end{array}$

$\begin{array}{llllllllll}\text { Minimum } & 8.807292 & 4.603923 & 3.403195 & 10.22384 & 15.58863 & 1.791759 & 2.968532 & 7.728854 & 1.062642\end{array}$

Std. Dev. $\quad \begin{array}{llllllllll}0.664106 & 0.311348 & 0.611823 & 0.809726 & 0.355447 & 0.303638 & 0.522377 & 1.674863 & 0.457919\end{array}$

$\begin{array}{llllllllll}\text { Skewness } & -0.860583 & 1.181092 & -0.089322 & -0.374970 & -0.447976 & -0.742269 & -0.279429 & -0.128544 & -0.614539\end{array}$

$\begin{array}{llllllllll}\text { Kurtosis } & 2.264442 & 3.506520 & 1.953984 & 2.211563 & 1.975102 & 3.229659 & 1.953584 & 2.173366 & 2.400344\end{array}$

$\begin{array}{lllllllllll}\text { Jarque-Bera } & 11.09430 & 18.48216 & 3.565865 & 3.749471 & 5.868291 & 7.145887 & 4.456474 & 2.373156 & 5.922358\end{array}$

$\begin{array}{lllllllllll}\text { Probability } & 0.003899 & 0.000097 & 0.168144 & 0.153396 & 0.053176 & 0.028073 & 0.107718 & 0.305264 & 0.051758\end{array}$

$\begin{array}{lllllllllll}\text { Sum } & 771.8322 & 382.8259 & 346.9368 & 899.7773 & 1236.569 & 189.9960 & 308.6481 & 846.8308 & 164.7689\end{array}$

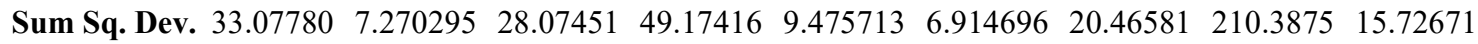

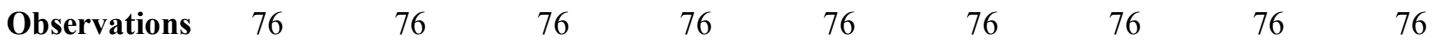

Table 1 above presents the statistics of key macroeconomic variables under consideration in $\log$ form. The average log of external reserves is 10.1556 , while that of the exchange rate shows an average of 5.0372. Based on the results of the Jarque-Bera test for normality, we reject the null hypothesis of normality in the two series at 5\% significant level.

The Correlation Matrix

It controls extent of affiliation prevailing amongst variables of consideration. The matrix determines the capacity and route of linear affiliation amongst two variables which exist in between as well as nearer the correlation coefficient is to $-1 /+1$ a perfect linear and harder affiliation exists amongst the variables. Table 1 , the correlation coefficients of the several variables (External reserves (EXTR), trade openness (TRADO), exchange rate (EXR), direct investment (DI), portfolio investment (PI), oil price (OP), Consumer price index (CPI), interest rate (INTR) is presented Table 2

Table2: Correlation matrix of the selected key macroeconomic indicators

\begin{tabular}{|c|c|c|c|c|c|c|c|c|c|}
\hline & EXTR & GDP & DI & $\mathrm{PI}$ & INTR & TRADO & OP & $\mathrm{CPI}$ & EXR \\
\hline EXTR & 1 & & & & & & & & \\
\hline GDP & $.583^{* *}$ & 1 & & & & & & & \\
\hline DI & $.596^{\star *}$ & $.510^{\star *}$ & 1 & & & & & & \\
\hline PI & $.396^{\star *}$ & $.562^{* *}$ & $.267^{*}$ & 1 & & & & & \\
\hline INTR & $-.710^{* *}$ & $-.424^{\star *}$ & $-.594^{\star *}$ & -.047 & 1 & & & & \\
\hline TRADO & $.723^{\star *}$ & $.759^{\star *}$ & $.516^{\star *}$ & $.586^{* *}$ & $-.622^{\star *}$ & 1 & & & \\
\hline OP & $.767^{\star \star}$ & $.547^{\star *}$ & $.557^{\star \star}$ & $.379^{* \star}$ & $-.662^{* *}$ & $.852^{\star \star}$ & 1 & & \\
\hline CPI & $.457^{\star *}$ & $.921^{\star *}$ & $.375^{\star *}$ & $.666^{\star *}$ & $-.285^{\star \star}$ & $.729^{\star *}$ & $.412^{\star *}$ & 1 & \\
\hline EXR & $.243^{*}$ & $.742^{\star \star}$ & $.287^{*}$ & $.608^{* \star}$ & -.098 & $.549^{\star *}$ & .144 & $.925^{\star \star}$ & 1 \\
\hline
\end{tabular}

**. Correlation is significant at the 0.01 level (2-tailed).

*. Correlation is significant at the 0.05 level (2-tailed).

Table 2 gives correlation matrix for selected macroeconomic variables utilised in this research. Exchange rate and consumer price index has a correlation of $92.5 \%$ and is highly significant at $5 \%$ significant level. The correlation coefficient amongst external reserve with other key macroeconomic variables are displayed on column exchange rate precisely, the coefficients of external reserve versus direct investment, trade openness and oil price are $59.6 \%, 72.3 \%$ and $76.7 \%$ respectively. These three coefficients are quite high and are all significant ant $5 \%$ significant level. Other coefficient levels are clearly shown in Table 2.

\subsection{The Unit Root Test}

The tests done in this research shows that all variables LEXTR, LEXR, LOP, LDI, LPI, LTRADO, LCPI, and LINTR are stationary and integrated of order one except LGDP which is stationary at level.

This is because the absolute values of the ADF test-statistic are greater than tabulated ADF critical values of variables at 5\% level of significance except for LCPI which is at 10\% level. This information is displayed below. 
Table 3: Stationarity Test using Augmented Dickey-Fuller (ADF)

\begin{tabular}{|c|c|c|c|}
\hline VARIABLE & ADF & CRITCAL VALUE & ORDER OF INTEGRATION \\
\hline LEXTR & $-4.991254^{*}$ & $-2.901217^{*}$ & $\mathrm{I}(1)$ \\
\hline LGDP & $-3.526278^{*}$ & $-2.904198^{*}$ & $\mathrm{I}(0)$ \\
\hline LTRADO & $-4.980127^{*}$ & $-2.903566^{*}$ & $\mathrm{I}(1)$ \\
\hline LEXR & $-7.227886^{*}$ & $-2.901217^{*}$ & $\mathrm{I}(1)$ \\
\hline LDI & $-10.63105^{*}$ & $-2.901217^{*}$ & $\mathrm{I}(1)$ \\
\hline LPI & $-12.6216^{*}$ & $-2.901217^{*}$ & $\mathrm{I}(1)$ \\
\hline LOP & $-6.531722^{*}$ & $-2.901779^{*}$ & $\mathrm{I}(1)$ \\
\hline LCPI & $-2.75096^{*}$ & $-2.589907^{*}$ & $\mathrm{I}(1)$ \\
\hline LINTR & $-4.980127^{*}$ & $-2.903566^{*}$ & \\
\hline
\end{tabular}

Note *stationary at $10 \%$ significance level, ${ }^{* *}$ stationary at $5 \%$ significance level

\subsection{Co-integration Test}

The Bounds co-integration test was conducted because series were integrated of diverse orders i.e. I (1) and I (0). From the co-integration test result, it was found that the variables for the equations were co-integrated as the null hypothesis is rejected following that the critical F-Statistics is larger than the value for the higher bound I (1) at $5 \%$ level of significance hence, approximation of both long and short run model. Table 4 presents the outcome of the limit's co-integration test conducted on the series.

Table 4: The Bound Test

\begin{tabular}{|c|c|c|c|c|}
\hline \multirow{2}{*}{\begin{tabular}{|l|} 
F-Bounds Test \\
Test Statistic \\
\end{tabular}} & \multicolumn{4}{|c|}{ Null Hypothesis: No levels relationship } \\
\hline & Value & Signif. & $\mathrm{I}(0)$ & $\mathrm{I}(1)$ \\
\hline & \multicolumn{4}{|c|}{$\begin{array}{l}\text { Asymptotic: } \\
\mathrm{n}=1000\end{array}$} \\
\hline F-statistic & 4.383857 & $10 \%$ & 1.95 & 3.06 \\
\hline \multirow[t]{3}{*}{$\mathrm{K}$} & 8 & $5 \%$ & 2.22 & 3.39 \\
\hline & & $2.5 \%$ & 2.48 & 3.7 \\
\hline & & $1 \%$ & 2.79 & 4.1 \\
\hline \multicolumn{5}{|c|}{$\begin{array}{c}\text { Finite Sample: } \\
\mathrm{n}=75\end{array}$} \\
\hline & & $10 \%$ & -1 & -1 \\
\hline & & $5 \%$ & -1 & -1 \\
\hline & & $1 \%$ & -1 & -1 \\
\hline \multicolumn{5}{|c|}{$\begin{array}{c}\text { Finite Sample: } \\
n=70\end{array}$} \\
\hline & & $10 \%$ & -1 & -1 \\
\hline & & $5 \%$ & -1 & -1 \\
\hline & & $1 \%$ & -1 & -1 \\
\hline t-Bounds Test & \multicolumn{4}{|c|}{ Null Hypothesis: No levels relationship } \\
\hline Test Statistic & Value & Signif. & $\mathrm{I}(0)$ & $\mathrm{I}(1)$ \\
\hline t-statistic & -1.103578 & $10 \%$ & -2.57 & -4.4 \\
\hline & & $5 \%$ & -2.86 & -4.72 \\
\hline & & $2.5 \%$ & -3.13 & -5.02 \\
\hline & & $1 \%$ & -3.43 & -5.37 \\
\hline
\end{tabular}

The diagnostic tests (serial correlation, normality, linearity and heteroskedasticity) carried out were all insignificant. The CUSUM and CUSUM square tests were conducted to check if there exist any recursive residual as ARDL is sensitive to it and from the test, it was found that there was no issue of recursive residual in terms of the mean as the plots of CUSUM and CUSUM square for the models were around the $5 \%$ critical bound. This implies the parameters of the model do not suffer any structural break within the scope of research. The outcome of the tests can be found below: 


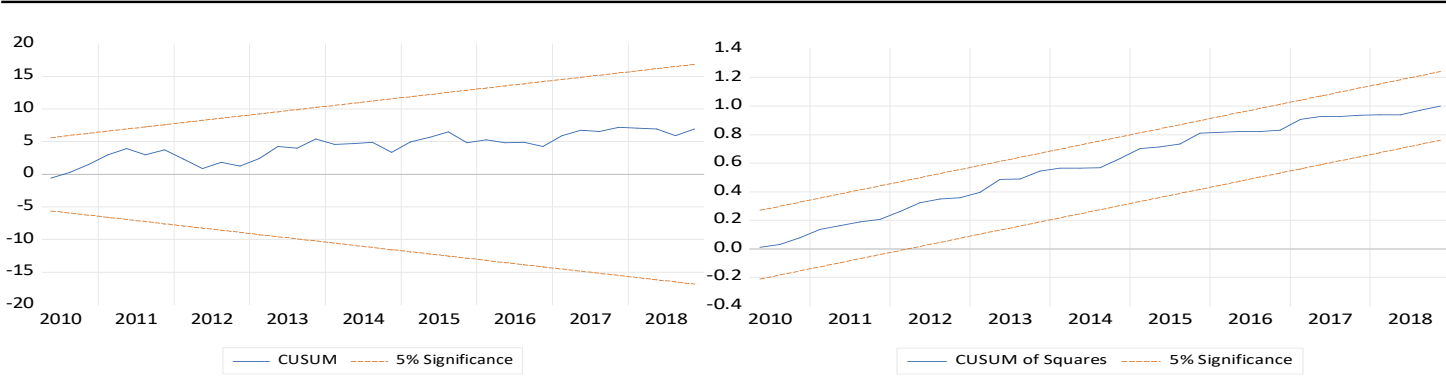

Figure 2: CUSUM and CUSUMSQ Stability Tests

Precisely, stability test outcomes are plotted in Figures $1 \mathrm{a}$ and $1 \mathrm{~b}$. The CUSUM stability test shows that the External reserve function was stable for the entire period from 2010 and 2018 . This is because at $5 \%$ significance level, the statistic completely lied within critical region.

Similarly, the CUSUM squares test also shows that the external reserve model was stable at 5\% critical level.

4.3 Estimation Result and Discussion

Table 5: Autoregressive Distributed Lag Estimates of the model

ARDL $(3,4,3,3,4,4,2,3,2)$

\begin{tabular}{|c|c|c|c|c|}
\hline Variables & Coefficients & Standard Error & t-Statistics & Probability \\
\hline $\operatorname{LEXTR}(-1)$ & 0.8043 & 0.1336 & 6.0189 & 0.0000 \\
\hline $\operatorname{LEXTR}(-2)$ & 0.5093 & 0.2094 & 2.4320 & 0.0203 \\
\hline $\operatorname{LEXTR}(-3)$ & -0.3803 & 0.1489 & -2.5533 & 0.0152 \\
\hline LGDP & -1.1862 & 0.4602 & -2.5778 & 0.0143 \\
\hline $\operatorname{LGDP}(-1)$ & 0.0978 & 0.3080 & 0.3174 & 0.7528 \\
\hline $\operatorname{LGDP}(-2)$ & -0.3374 & 0.3272 & -1.0309 & 0.3096 \\
\hline $\operatorname{LGDP}(-3)$ & -0.4538 & 0.3454 & -1.3137 & 0.1975 \\
\hline $\operatorname{LGDP}(-4)$ & 0.7383 & 0.4804 & 1.5369 & 0.1333 \\
\hline LEXR & -0.9363 & 0.2549 & -3.6737 & 0.0008 \\
\hline $\operatorname{LEXR}(-1)$ & 0.3772 & 0.2833 & 1.3311 & 0.1918 \\
\hline $\operatorname{LEXR}(-2)$ & -0.0410 & 0.2918 & -0.1405 & 0.8890 \\
\hline $\operatorname{LEXR}(-3)$ & -0.5391 & 0.2290 & -2.3540 & 0.0243 \\
\hline LOP & 0.2234 & 0.0847 & 2.6364 & 0.0124 \\
\hline $\operatorname{LOP}(-1)$ & -0.1945 & 0.1262 & -1.5406 & 0.1324 \\
\hline $\operatorname{LOP}(-2)$ & -0.2904 & 0.1137 & -2.5540 & 0.0152 \\
\hline $\operatorname{LOP}(-3)$ & -0.1287 & 0.1066 & -1.2075 & 0.2353 \\
\hline LDI & 0.0758 & 0.0268 & 2.8283 & 0.0077 \\
\hline LDI(-1) & 0.0151 & 0.0270 & 0.5594 & 0.5794 \\
\hline LDI(-2) & -0.0370 & 0.0270 & -1.3731 & 0.1785 \\
\hline LDI(-3) & 0.0751 & 0.0315 & 2.3845 & 0.0227 \\
\hline LDI(-4) & -0.0340 & 0.0317 & -1.0725 & 0.2908 \\
\hline LPI & 0.0388 & 0.0136 & 2.8456 & 0.0074 \\
\hline LPI(-1) & -0.0131 & 0.0145 & -0.9073 & 0.3704 \\
\hline LPI(-2) & -0.0343 & 0.0139 & -2.4751 & 0.0183 \\
\hline LPI(-3) & -0.0162 & 0.0138 & -1.1758 & 0.2476 \\
\hline LPI(-4) & -0.0235 & 0.0138 & -1.7026 & 0.0975 \\
\hline LCPI & -0.9543 & 0.4146 & -2.3019 & 0.0274 \\
\hline LCPI(-1) & 0.2707 & 0.5011 & 0.5403 & 0.5924 \\
\hline LCPI $(-2)$ & 1.7508 & 0.4226 & 4.1429 & 0.0002 \\
\hline LTRADO & 0.0478 & 0.1293 & 0.3700 & 0.7136 \\
\hline LTRADO(-1) & 0.2374 & 0.1214 & 1.9562 & 0.0585 \\
\hline LTRADO(-2) & 0.1455 & 0.1009 & 1.4428 & 0.1580 \\
\hline LTRADO(-3) & 0.1378 & 0.0953 & 1.4461 & 0.1570 \\
\hline LINTR & 0.0862 & 0.1275 & 0.6762 & 0.5034 \\
\hline LINTR(-1) & -0.0504 & 0.1371 & -0.3679 & 0.7151 \\
\hline LINTR(-2) & 0.2136 & 0.0989 & 2.1607 & 0.0376 \\
\hline $\mathrm{C}$ & 19.3683 & 9.2203 & 2.1006 & 0.0429 \\
\hline R-Sqd. & 0.9953 & Mean dependent variance & & 10.2220 \\
\hline
\end{tabular}


ARDL $(3,4,3,3,4,4,2,3,2)$

\begin{tabular}{|c|c|c|c|c|}
\hline Variables & Coefficients & Standard Error & t-Statistics & Probability \\
\hline Adj. R-sqd. & 0.9905 & S.D. dependent variance & & 0.6166 \\
\hline S.E.R & 0.0601 & Akaike info criterion & & -2.4777 \\
\hline SSR & 0.1266 & Schwarz criterion & & -1.3077 \\
\hline Log likelihood & 126.1963 & Hannan-Quinn criterion. & & -2.0119 \\
\hline F-stat. & 206.3374 & Durbin-Watson stat. & & 2.1645 \\
\hline Prob (F-stat.) & 0.0000 & & & \\
\hline
\end{tabular}

As shown in above Table 5; The constants of the estimated ARDL all met the a priori expectation of positive coefficient indicating positive impact though some variables as LGDP, LEXTR, LEXR and LCPI showed a positive impact in the previous period.

\subsection{Estimated Long -run coefficients}

The co-integration test showed that the series were correlated, so we went ahead to estimate long and short run model as specified in equation (4) above. The second stage of the ARDL, the approximations of the long-run constants was computed using AIC.

Table 6 displays the summary outcomes of the projected long -run constants.

Table 6: Summary result of estimated long- run constant

\begin{tabular}{|c|r|r|r|r|}
\hline Variable & Coefficient & Std. Error & t-Statistic & Prob. \\
\hline LGDP & -17.09557 & 12.20485 & -1.400719 & 0.1701 \\
\hline LEXR & -17.06532 & 15.09865 & -1.130254 & 0.2661 \\
\hline LOP & -5.845511 & 6.983131 & -0.837090 & 0.4082 \\
\hline LDI & 1.423112 & 1.298366 & 1.096080 & 0.2805 \\
\hline LPI & -0.723656 & 0.709159 & -1.020442 & 0.3145 \\
\hline LCPI & 15.98573 & 11.94845 & 1.337892 & 0.1896 \\
\hline LTRADO & 8.516287 & 9.266915 & 0.918999 & 0.3644 \\
\hline LINTR & 3.736631 & 4.481080 & 0.833869 & 0.4100 \\
\hline
\end{tabular}

The anticipated constants of the long run relationship are inconsequential for all the variables but then again positive for LDI, LCPI, LTRADO and LINTR while LGDP, LEXR, LOP and LPI are negative. This indicates that LDI, LCPI, LTRADO and LINTR have a reassuring statistical influence on external reserves level whereas LGDP, LEXR, LOP and LPI have a undesirable influence on external reserves on the long run.

\subsection{Error Correction Model}

The ECM corresponding to long run estimates for carefully chosen ARDL Model was evaluated. The estimated ECM of Table 7 has two portions. First part comprises the projected constants of short run dynamics and the second portion contains of the approximations of ECT regulates swiftness of modification in which short-run dynamics congregate to long-run symmetry track in the model.

Table 7: Estimated Error Correction Model (ECM)

\begin{tabular}{|c|c|c|c|c|}
\hline Variables & Coefficients & Standard Error & T-Statistic & Probability \\
\hline C & 19.3683 & 2.7764 & 6.9761 & 0.0000 \\
\hline $\mathrm{D}($ LEXTR(-1)) & -0.1290 & 0.1056 & -1.2208 & 0.2303 \\
\hline $\mathrm{D}($ LEXTR(-2)) & 0.3803 & 0.1044 & 3.6430 & 0.0009 \\
\hline $\mathrm{D}(\mathrm{LGDP})$ & -1.1862 & 0.2836 & -4.1820 & 0.0002 \\
\hline $\mathrm{D}(\mathrm{LGDP}(-1))$ & 0.0529 & 0.2474 & 0.2137 & 0.8320 \\
\hline $\mathrm{D}(\mathrm{LGDP}(-2))$ & -0.2845 & 0.2665 & -1.0674 & 0.2931 \\
\hline $\mathrm{D}(\mathrm{LGDP}(-3))$ & -0.7383 & 0.2804 & -2.6325 & 0.0125 \\
\hline $\mathrm{D}(\mathrm{LEXR})$ & -0.9363 & 0.1898 & -4.9339 & 0.0000 \\
\hline $\mathrm{D}(\mathrm{LEXR}(-1))$ & 0.5801 & 0.1760 & 3.2959 & 0.0023 \\
\hline $\mathrm{D}(\mathrm{LEXR}(-2))$ & 0.5391 & 0.1673 & 3.2217 & 0.0028 \\
\hline $\mathrm{D}(\mathrm{LOP})$ & 0.2234 & 0.0649 & 3.4445 & 0.0015 \\
\hline $\mathrm{D}(\mathrm{LOP}(-1))$ & 0.4191 & 0.0939 & 4.4620 & 0.0001 \\
\hline $\mathrm{D}(\mathrm{LOP}(-2))$ & 0.1287 & 0.0731 & 1.7605 & 0.0871 \\
\hline $\mathrm{D}(\mathrm{LDI})$ & 0.0758 & 0.0209 & 3.6271 & 0.0009 \\
\hline $\mathrm{D}(\mathrm{LDI}(-1))$ & -0.0041 & 0.0208 & -0.1952 & 0.8464 \\
\hline $\mathrm{D}(\mathrm{LDI}(-2))$ & -0.0411 & 0.0206 & -1.9928 & 0.0541 \\
\hline $\mathrm{D}(\mathrm{LDI}(-3))$ & 0.0340 & 0.0232 & 1.4661 & 0.1515 \\
\hline $\mathrm{D}(\mathrm{LPI})$ & 0.0388 & 0.0106 & 3.6688 & 0.0008 \\
\hline
\end{tabular}




\begin{tabular}{|c|c|c|c|c|}
\hline Variables & Coefficients & Standard Error & T-Statistic & Probability \\
\hline D(LPI(-1)) & 0.0740 & 0.0124 & 5.9440 & 0.0000 \\
\hline D(LPI(-2)) & 0.0397 & 0.0121 & 3.2851 & 0.0023 \\
\hline D(LPI(-3)) & 0.0235 & 0.0105 & 2.2453 & 0.0312 \\
\hline D(LCPI) & -0.9543 & 0.3149 & -3.0303 & 0.0046 \\
\hline D(LCPI(-1)) & -1.7508 & 0.3318 & -5.2766 & 0.0000 \\
\hline D(LTRADO) & 0.0478 & 0.0939 & 0.5095 & 0.6136 \\
\hline D(LTRADO(-1)) & -0.2833 & 0.0908 & -3.1193 & 0.0036 \\
\hline D(LTRADO(-2)) & -0.1378 & 0.0745 & -1.8487 & 0.0730 \\
\hline D(LINTR) & 0.0862 & 0.0826 & 1.0435 & 0.3039 \\
\hline D(LINTR(-1)) & -0.2136 & 0.0810 & -2.6371 & 0.0124 \\
\hline Coint. Eq (-1)* & -0.0668 & 0.0096 & -6.9623 & 0.0000 \\
\hline R-square & 0.8286 & Mean dep. Var. & & 0.0210 \\
\hline Adj. R-square & 0.7171 & S.D. dep. var. & & 0.1020 \\
\hline S.E. of regr. & 0.0543 & Akaike I.C & & -2.6999 \\
\hline S.S resid. & 0.1266 & Schwarz criterion & & -1.7829 \\
\hline Log likelihood & 126.1963 & Hannan-Quinn criter. & & -2.3348 \\
\hline F-stat. & 7.4264 & Durbin-Watson stat & & 2.1645 \\
\hline Prob (F-stat.) & 0.0000 & & & \\
\hline The & & & \\
\hline
\end{tabular}

The short-run constants evaluations show the dynamic modification of several variables. The short run constants for all the variables are significant though some at previous period. The constant of ECM (-1) is negative and exceedingly substantial signifying that the variables are cointegrated completely. The projected cost of the constant shows that approximately 6.68 per cent of the volatility in external reserve is counterbalance by the short run modification. This, however, indicates a very slow swiftness of modification between the variables, meaning that previous errors of relationship in reserves and designated macroeconomic variables are adjusted in existing time however, at sluggish rate.

Figure 2: Movements in the selected variables during the period of research (2000Q1-2018Q4)

Log Differenced LEXTR

.03

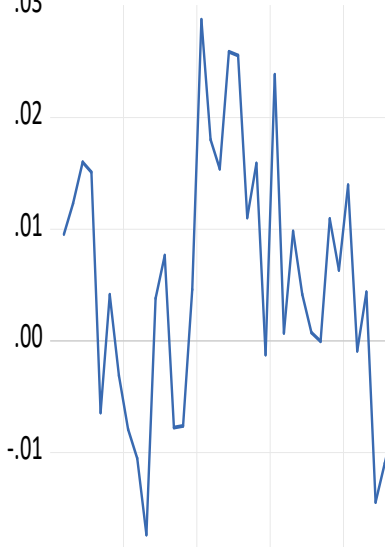

$-.02$

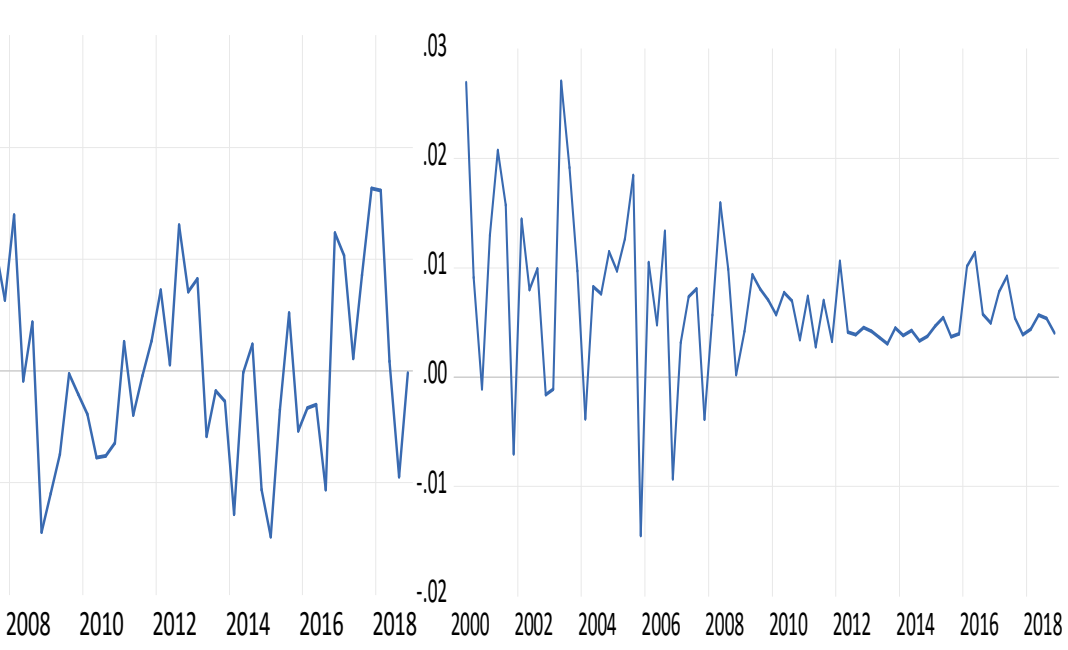


LD|

\begin{tabular}{l|l}
13.5 & 07
\end{tabular}

13.0

12.5

12.0

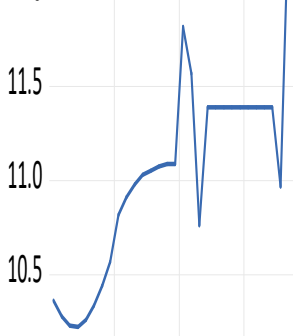

10.0
.07

Log Differenced LEXR 
LOP

5.2

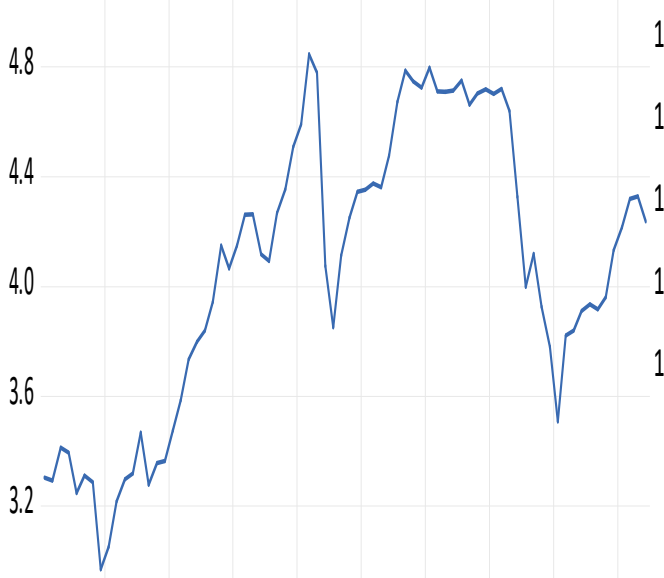

2.8
15

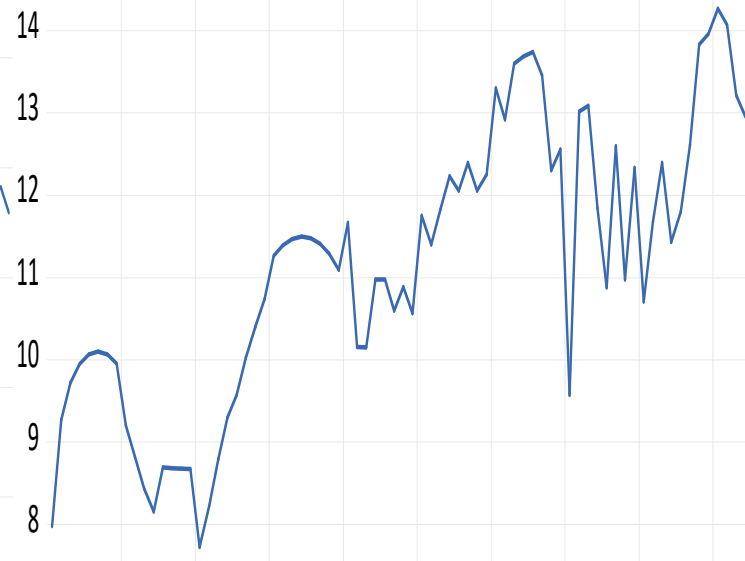

7
LPI
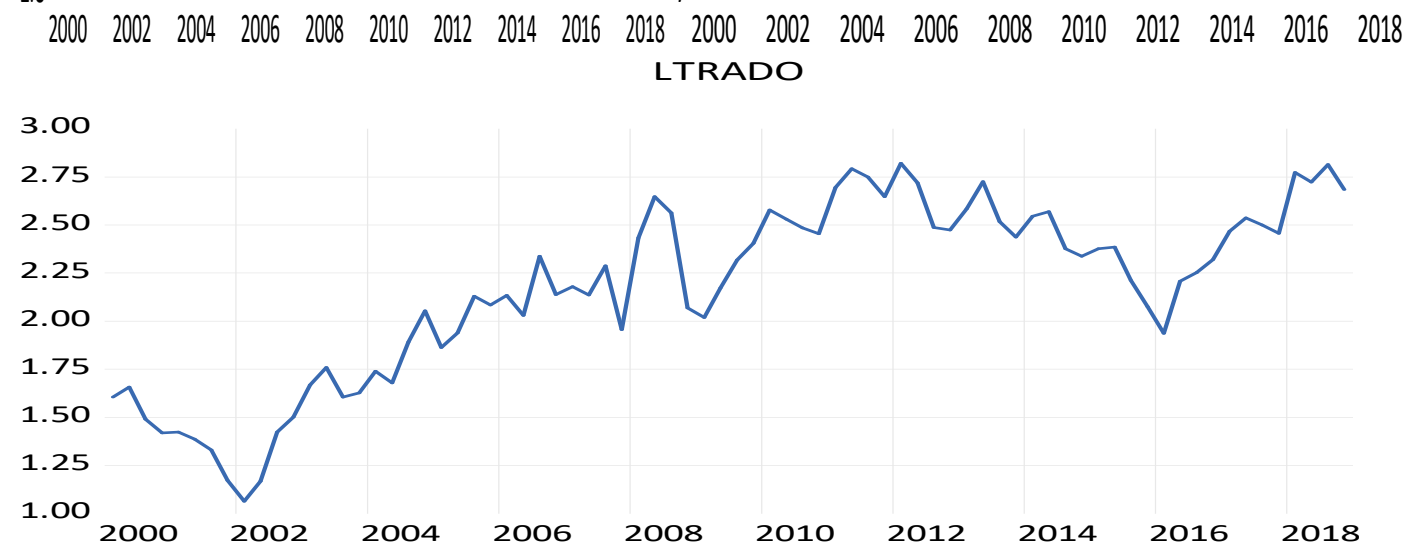

\subsection{Concluding Remarks}

This study has examined the movements and scientific connections of reserve with some macroeconomic variables, namely GDP, exchange rate, consumer price index, oil price, trade openness, level of capital inflow (direct investment and portfolio investment) and interest rate in Nigeria. The matters of structural breaks, cointegration and steadiness of external reserve drive in Nigeria throughout 2000:Q1 and 2018:Q4 were studied. The Gregory-Hansen test was used to perceive probable structural breaks and evaluate cointegrating model. The device determines short run dynamics with steadiness of foreign exchange drive. Nigeria's external reserves has been reliably pretentious by international oil price, economic and financial influences. On the short run when various prices in the economy can change, activities in nominal exchange rates can change comparative prices and interrupt external trade flows. The best Autoregressive Distributed Lag Estimates of the model was determined at ARDL(3,4,3,3,4,4,2,3,2). The CUSUM and CUSUMSQ functions of Brown et al. (1975) was used to adjust provided external reserve drive for Nigeria is steady during the study period. Each time the repetition of the remaining evaluated external reserve purpose is found in between borders of two risky lines, then there is an indication of constraint volatility at the time. In this study, CUSUM and CUSUMSQ models demonstrates outstanding repetition schemes for external reserve drive within 5\% critical lines, showing indication of steady external reserve drive for Nigeria. This displays that the external reserve function was stable during the period 2000 to 2018, which therefore suggests that external reserve function is stable for the period under consideration. The results show that LDI, LCPI, LTRADO and LINTR positively affect the extent of reserve on the long- run whereas LOP, LDI, LPI, LTRADO and LINTR have positive effect, statistically significant and contributes to reserves position in Nigeria on the short- run. It is therefore necessary for policy makers in the country to always monitor the impact of these key macroeconomic variables on external reserves so as to help monetary authority in exchange rate policy and foreign investors in the investment models to adopt in both short and long run. 


\section{REFERENCES}

Alabi M. K, Ojuolape, M. A \& Yusuf, H. A (2017). The Impact of Accumulating Foreign Reserves on Economic Growth in Nigeria. Department of Economics, University of Ilorin. Sokoto Journal of Social Sciences Volume 7, number 2.

Archer, D and Halliday, J., (1998). "The rationale for holding foreign currency reserves" Reserve Bank of new Zealand Bulletin, 61

Borivoje, D. K and Tina, M., (2015). Empirical analysis of the impact of external reserves to economic growth in emerging economies. Applied Economics and Finance,Vol. 2, No. 1; February 2015

Brown, R. L., J. Durbin, and J. M. Evans (1975): "Techniques for Testing the Constancy of Regression Relationships Over Time”, Journal of the Royal Statistical Society, Series B(37):149-192

Elhiraika, A., and Ndikumana, L., (2007). Reserves Accumulation in African Countries: Sources, Motivations and Effects, University of Massachusetts Amherst Working Paper, 2007-12, pp 1-27

Fischer, S. (2001). Opening remarks, IMF/World Bank International reserves forum, IMF Washington DC.

Frenkel, J. A and Jovanovic, B. (1981). Optimal International Reserves: A Stochastic Framework. The Economic Journal, 91(June)

Fukuda, S and Y. Kon. 2010. Macroeconomic Impacts of Foreign Exchange Reserve Accumulation: Theory and International Evidence. ADBI Working Paper 197. Tokyo: Asian Development Bank Institute.

Ghosh, R., Ostry, J., \& Tsangarides, C. (2012). Shifting motives: Explaining the buildup in official reserves in emerging markets since the 1980s, IMF Working Papers.

Greenspan (1999); Currency Reserves and Debt. Currency Reserves and Debt Remarks by the Chairman at the World Bank Conference

Gregory, A.W. and Hansen, B.E. (1996) Residual-based Tests for Cointergation in Models with Regime Shifts, Journal of Econometrics, 70, 99 - 126.

Heller, H. R \& Khan, M., (1978); the demand for international reserves under fixed and floating exchange rates.

International Monetary Fund. (2003). Guidelines for Foreign Exchange Reserve Management. IMF, June.

IMF (2009b). Balance of Payments and International Investment Position Manual, 6th edition.

IMF (2011). Assessing Reserve Adequacy, Monetary and Capital Markets, Research, and Strategy, Policy, and Review Departments

Jovanovic, B., and Frenkel, J. (1981). Optimal international reserves. Economic Journal, 91(362), 507-514.

Kevin Greenidge et al. (2009). Macroeconomic effect on foreign exchange reserve

Lin, M., and Wang, J. (2005), Foreign Exchange Reserves and Inflation: An Empirical Study of five East Asia Economies.Aletheia University, Taiwan and National Chengchi University, Taiwan.Pp 1-18.

Marc-Andre, G and Nicholas, P. (2005). An Empirical Analysis of Foreign Exchange Reserves in Emerging Asia. Bank of Canada working paper, No.2005-38

Olokoyo, Osabuohien \& Salami (2009). Econometric Analysis of Foreign Reserves and Some Macroeconomic Variables in Nigeria (1970-2007) African Development Review, Vol. 21, No. 3, 2009, 454-475

Nzotta, S.M. (2004). Money, Banking and Finance (Theory and Practice), Hudson- Jude Nigeria Publishers, Owerri.

Osuji C and Ebiringa, O.T (2012); Analysis of Effect of External Reserves Management on Macroeconomic Stability of Nigeria

Pesaran, M. H and Pesaran, B. (1997) Working with Microfit 4.0: Interactive Econometric Analysis, Oxford University Press, Oxford.

Steiner, A., (2010) Central Banks' Dilemma: Reserves Accumulation, Inflation and Financial Instability, Grade School of Economic, A Social Sciences, University of Mannheim, Germany. Pp 1-31

Usman, A. and Waheed, I (2010), External Reserves Holding in Nigeria: Implications for Investment Inflation and Exchange Rate, Journal of Economics and International finance 2(9). Pp 183-192

Umeora, C. E., (2013) Foreign Exchange Reserves Accumulation and Macro-Economic Stability: The Nigerian Experience. International Journal of Business and Management Invention, Vol.2

Oputa, N.C. and T.S. Ogunleye (2010). "External Reserves Accumulation and the Estimation of the Adequacy Level for Nigeria". Economic and Financial Review, Volume 48/3. 